\title{
АКУШЕРСТВО. ГИНЕКОЛОГИЯ
}

UDC 616.61:616.62-008.222

\section{N. A. Osipova, D. A. Niauri, A. M. Gzgzyan, L. Kh. Dzhemlikhanova \\ CORRECTION OF RENAL FUNCTION BY DESMOPRESSIN AND DICLOFENAC IN INCONTINENT WOMEN WITH NOCTURIA}

St Petersburg State University, 7-9, Universitetskaya nab., St. Petersburg, 199034, Russian Federation

The purpose of this study was to evaluate the clinical efficiency of desmopressine and diclofenac in incontinent patients with nocturnal polyuria and polyuria. A total of 277 patients $\geq 18 \leq 55$ years of age with complaints of urinary incontinence were included. 143 women had stress incontinence, 43 - urge incontinence and 91 - mixed incontinence. The overall prevalence of nocturia was $34.7 \pm 2.9 \%$ (96 women). The frequency of poliuriya was $7 \pm 2.1 \%$ in stress incontinence, $11.6 \pm 4.9 \%$ in urge incontinence and $9.9 \pm 3.1 \%$ in mixed incontinence $(\mathrm{p}>0.05)$. The frequency of nocturnal polyuria was $17.5 \pm 3.2 \%$ in stress incontinence, $27.9 \pm 6.8 \%$ in urge incontinence and $25.3 \pm 4.6 \%$ mixed incontinence $(\mathrm{p}>0.05)$. Patients were randomized to receive either desmopressin or diclofenac in a double - blind fashion. The statistically significant recovery of renal function occurred in 8 incontinent women with polyuria and 19 with nocturnal polyuria who received diclofenac and in 12 incontinent women with polyuria and 18 with nocturnal polyuria who received desmopressin (Minirin). Refs 5 . Figs 12. Table 1. fenac.

Keywords: renal osmoregulatoin function, incontinence, sodium excretion, desmopressin, diclo-

\section{КОРРЕКЦИЯ ФУНКЦИИ ПОЧКИ ДЕСМОПРЕССИНОМ И ДИКЛОФЕНАКОМ У ЖЕНЩИН С НЕДЕРЖАНИЕМ МОЧИ И НОКТУРИЕЙ}

\section{Н. А. Осипова, Д. А. Ниаури, А. М. Гзгзян, Л. Х. Джемлиханова}

Санкт-Петербургский государственный университет,

Российская Федерация, 199034, Санкт-Петербург, Университетская наб., 7-9

Настоящее исследование было проведено с целью оценки клинической эффективности десмопрессина и диклофенака при недержании мочи у женщин с ноктурией и полиурией. В исследование были включены 277 пациенток в возрасте $\geq 18 \leq 55$ лет с жалобами на недержание мочи. У 143 женщин было выявлено стрессовое недержание мочи, 43 - императивное и у $91-$ смешанное. Частота развития ноктурии составила $34.7 \pm 2.9 \%$ (96 женщин): $24.5 \pm 3.6 \%$ (35 женщин) со стрессовым недержанием мочи, $46.5 \pm 7.6 \%$ (20 женщин) с императивным ( $\mathrm{p}<0.01)$ и $45.1 \pm 5.2 \%$ (41женщина) со смешанным ( $<<0.01)$. Частота развития полиурии составила $7 \pm 2.1 \%$ при стрессовом недержании мочи, $11.6 \pm 4.9 \%-$ при императивном и $9.9 \pm 3.1 \%$ при смешанном ( $>0.05)$. Частота развития ноктурии составила $17.5 \pm 3.2 \%$ при стрессовом недержании мочи, $27.9 \pm 6.8 \%$ при императивном и $25.3 \pm 4.6 \%$ при смешанном недержании ( $>0.05)$. Нормализация функции почки произошла у 8 пациенток с полиурией и 19 - ноктурией, которые получали диклофенак и у 12 пациенток с полиурией и 18 с ноктурией, которые получали десмопрессин (Minirin). У этих пациенток было выявлено достовер-

(c) Санкт-Петербургский государственный университет, 2017 
ное снижение диуреза, экскреции осмотически активных веществ, а именно ионов натрия, калия, магния. Библиогр. 5 назв. Ил. 12. Табл. 1.

Ключевые слова: осморегулирующая функция, недержание, экскреция натрия, десмопрессин, диклофенак.

\section{Introduction}

Urine incontinence seems to include several pathogenic forms, as efficient therapy is provided by different medications. Commonly used in the treatment of female patients with overactive bladder and nocturia is desmopressin which normalizes the water excretion of the kidney, which is disturbed by a presumed inverted rhythm of vasopressin secretion in these patients [1]. Some drugs which eliminate disturbance of urinary bladder function are often used. The kidney may also be involved in the therapeutic effect of diclofenac which blocks prostaglandin synthase, as vasopressin and prostaglandins are known to act competitively in the regulation of renal water reabsorption [2]. The current analysis was undertaken to evaluate the clinical efficiency of desmopressine and diclofenac in incontinent patients with nocturia.

\section{Materials and methods}

277 patients $\geq 18 \geq 48$ years of age with complaints of urinary incontinence were analysed according to a specific protocol: urodynamic testing, transperineal ureterovesical segment ultrasonography, a 3-day frequency-volume (FV) chart. Nocturia was defined as two or more micturitions per night calculated from the FV chart. Night was defined as the period of sleep. All participants also performed 24h-urine collection to determine the voided volumes and the levels of creatinine, osmolality, sodium, magnesium and potassium for each sample. All urine samples collected for $24 \mathrm{~h}$ were divided into two 12 -h portions: night portion (23:00-07:00) and day portion (07:00-23:00). A blood sample was taken during the 24-urine collection to determine the levels of osmolality (using a MT-4 osmometer based on determination of freezing point depression, Burevestnik, Russia), creatinine, sodium, magnesium and potassium (using a Abbott Architect 8000). The examination of patients with nocturia was performed twice: in the initial state and 4 weeks after the start of treatment with desmopressin or diclofenac. Patients were randomized to receive either desmopressin or diclofenac in a double - blind fashion. Optimal dose was established through an open-label dose-titration using $0.1 \mathrm{mg}, 0.2 \mathrm{mg}$ and $0.4 \mathrm{mg}$ of desmopressin (Minirin) or diclofenac using $25 \mathrm{mg}, 50 \mathrm{mg}$ and $75 \mathrm{mg}$ twice a day for one week each. Patients received their optimal dose for 4 weeks. Safety parameters assessed included incidence of adverse events, vital signs and serum sodium levels. The differences in all parameters were treated statistically using Student $s$ t-test.

\section{Results}

According to a specific protocol 143 women had stress incontinence, 43 - urge incontinence and $91-$ mixed incontinence. The overall prevalence of nocturia was $34.7 \pm 2.9 \%$ (96 women): $24.5 \pm 3.6 \%$ in stress incontinence, $46.5 \pm 7.6 \%$ in urge incontinence $(\mathrm{p}<0.01)$ and $45.1 \pm 5.2 \%$ in mixed incontinence $(\mathrm{p}<0.01)$. The nocturics were classified into one of the responsible pathophysiologic categories [3]: nocturnal polyuria in $30 \pm 4.4 \%$ (33 women), a low functional bladder capacity in $12.5 \pm 3.4 \%$ 
(12 women), a combination of both in $28.1 \pm 4.6 \%$ (27 women), polyuria was diagnosed in $25.0 \pm 4.4 \%$ (24 women) of the cases. The frequency of polyuria (24-urine volume of $40 \mathrm{~mL} / \mathrm{kg}$ bodyweight or above) was $7 \pm 2.1 \%$ in stress incontinence , $11.6 \pm 4.9 \%$ in urge incontinence and $9.9 \pm 3.1 \%$ in mixed incontinence $(\mathrm{p}>0.05)$. The frequency of nocturnal polyuria (nocturnal volume / 24-h urine volume of 0.20 or above ) was $17.5 \pm 3.2 \%$ in stress incontinence, $27.9 \pm 6.8 \%$ in urge incontinence and $25.3 \pm 4.6 \%$ mixed incontinence $(p>0.05)$.

Lack of significant differences between the studied parameters in patients with nocturnal polyuria and polyuria and various types of urine incontinence has allowed to unite all samples of patients with polyuria $(n=24)$ and nocturnal polyuria $(n=60)$ for the further analysis. We have found previously that in patients with polyuria and nocturnal polyuria the glomerular filtration rate was normal, whereas diuresis and solute (sodium, magnesium, potassium) excretion in night samples in nocturnal polyuria and both in night and day samples in polyuria were increased [4]. The higher diuresis and the higher solute excretion observed in nocturnal polyuria and polyuria are accompanied by an increase of free water reabsorption. In nocturnal polyuria and polyuria a high correlation was found between the free water reabsorption and solute excretion (table 1). This occurs against the background of the high night and day osmotic concentration [4]. This study showed that the higher diuresis is accompanied by a reduction of ion reabsorption, firstly sodium and magnesium; as a result a higher excretion of solutes and water is observed.

Relation between diuresis, free water reabsorption and osmolal clearance; free water reabsorption, diuresis and solute excretion in incontinent women with nocturnal polyuria and polyuria

\begin{tabular}{|l|c|c|c|c|c|c|c|c|}
\hline \multirow{3}{*}{ Parameters } & \multicolumn{4}{|c|}{ Nocturnal polyuria } & \multicolumn{4}{c|}{ Polyuria } \\
\cline { 2 - 9 } & \multicolumn{2}{|c|}{$7.00-23.00$} & \multicolumn{2}{|c|}{$23.00-7.00$} & \multicolumn{2}{c|}{$7.00-23.00$} & \multicolumn{2}{c|}{$23.00-7.00$} \\
\cline { 2 - 9 } & $\mathbf{r}$ & $\mathbf{p}$ & $\mathbf{r}$ & $\mathbf{p}$ & $\mathbf{r}$ & $\mathbf{p}$ & $\mathbf{r}$ & $\mathrm{p}$ \\
\hline $\mathrm{V}-\mathrm{Cosm}$ & 0.74 & 0.01 & 0.81 & 0.01 & 0.68 & 0.01 & 0.72 & 0.01 \\
\hline $\mathrm{TCH}_{2} \mathrm{O}-\mathrm{Cosm}$ & 0.68 & 0.01 & 0.77 & 0.01 & 0.76 & 0.01 & 0.85 & 0.01 \\
\hline $\mathrm{TCH}_{2} \mathrm{O}-\mathrm{U}_{\mathrm{Na}} \mathrm{V}$ & 0.73 & 0.001 & 0.77 & 0.001 & 0.69 & 0.001 & 0.64 & 0.001 \\
\hline $\mathrm{TCH}_{2} \mathrm{O}-\mathrm{UM}_{\mathrm{g}} \mathrm{V}$ & 0.65 & 0.001 & 0.54 & 0.01 & 0.72 & 0.001 & 0.68 & 0.001 \\
\hline $\mathrm{V}-\mathrm{U}_{\mathrm{Na}} \mathrm{V}$ & 0.77 & 0.001 & 0.55 & 0.01 & 0.71 & 0.001 & 0.79 & 0.001 \\
\hline $\mathrm{V}-\mathrm{U}_{\mathrm{Mg}} \mathrm{V}$ & 0.74 & 0.001 & 0.68 & 0.001 & 0.57 & 0.01 & 0.47 & 0.05 \\
\hline
\end{tabular}

The statistically significant recovery of renal function occurred in 8 incontinent women with polyuria and 19 with nocturnal polyuria who received diclofenac and in 12 incontinent women with polyuria and 18 with nocturnal polyuria who received desmopressin (Minirin). In these patients there was a statistically significant decrease in diuresis, osmolar clearance and excretion of sodium, potassium and magnesium. Hence, the recovery of renal function was similar after treatment with desmopressin and diclofenac (picture 1-12). 


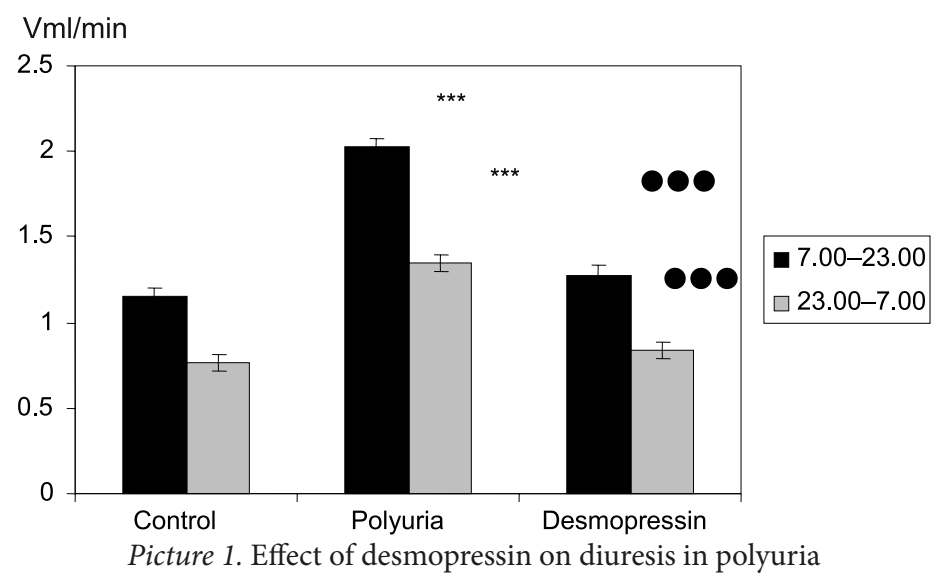

C osm $\mathrm{ml} / \mathrm{min}$

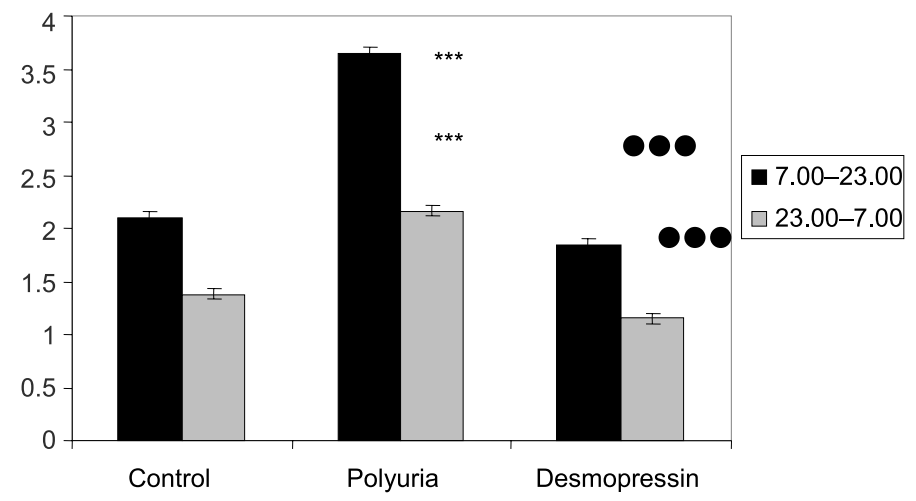

Picture 2. Effect of desmopressin on osmolal clearance in polyuria

Picture 1-3: ${ }^{* * *} \mathrm{p}<0.001,{ }^{* *} \mathrm{p}<0.01-$ compared with the same parameter in control group; $\bullet \bullet \bullet p<0.001, \bullet \bullet p<0.01-$ compared with the same parameter in polyuria group.

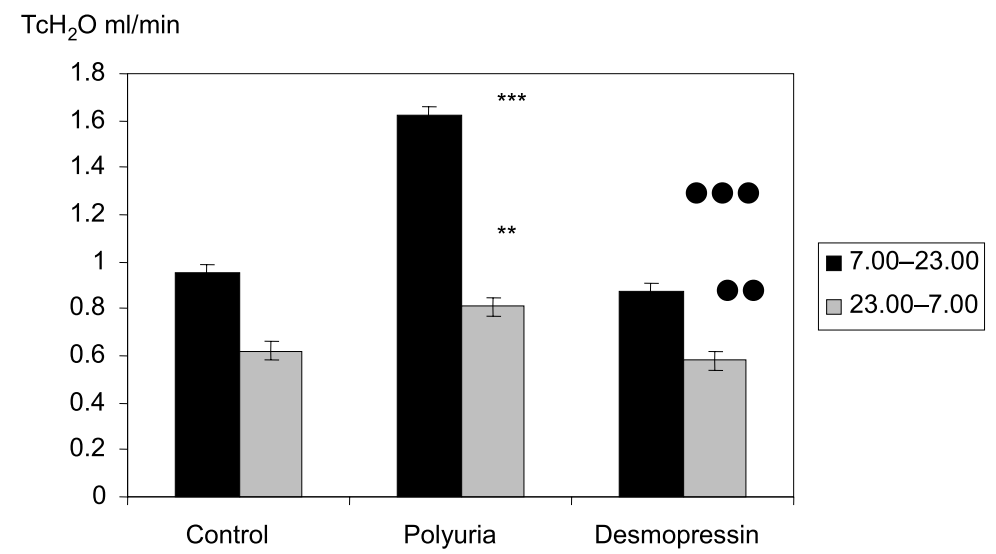

Picture 3. Effect of desmopressin on free water reabsorption in polyuria

Picture $1-3:{ }^{* *} \mathrm{p}<0.001,{ }^{* *} \mathrm{p}<0.01-$ compared with the same parameter in control group; $\bullet \bullet \bullet p<0.001, \bullet \bullet p<0.01-$ compared with the same parameter in polyuria group. 


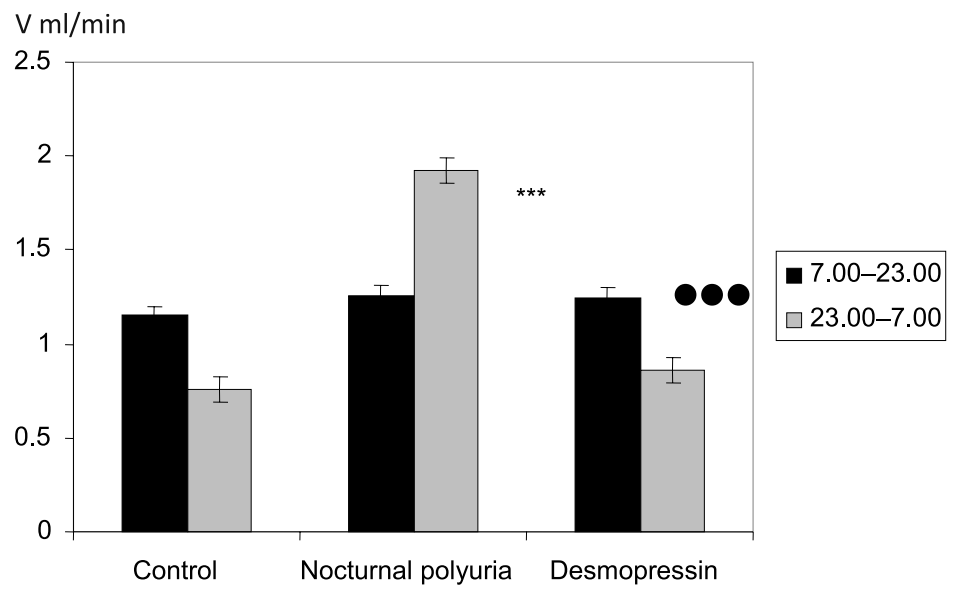

Picture 4. Effect of desmopressin on diuresis in nocturnal polyuria

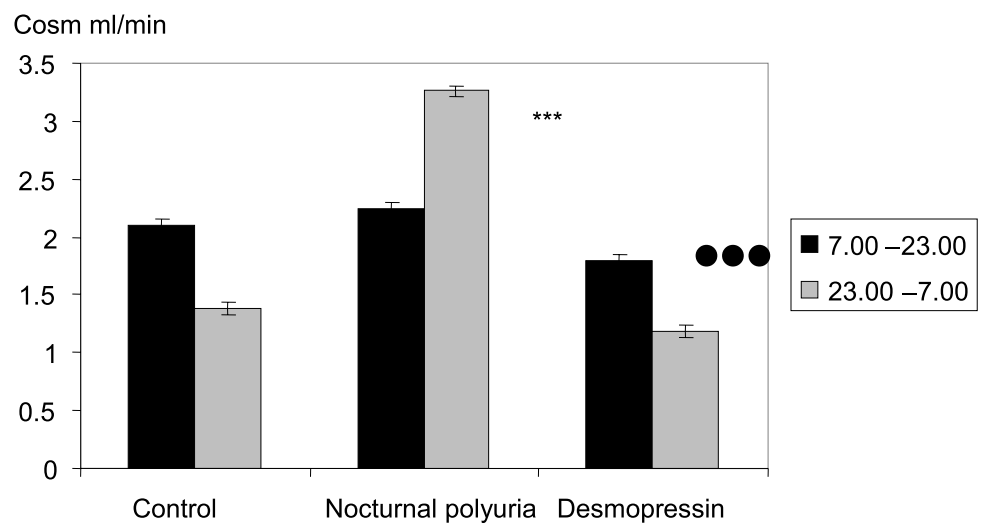

Picture 5. Effect of desmopressin on osmolal clearance in nocturnal polyuria

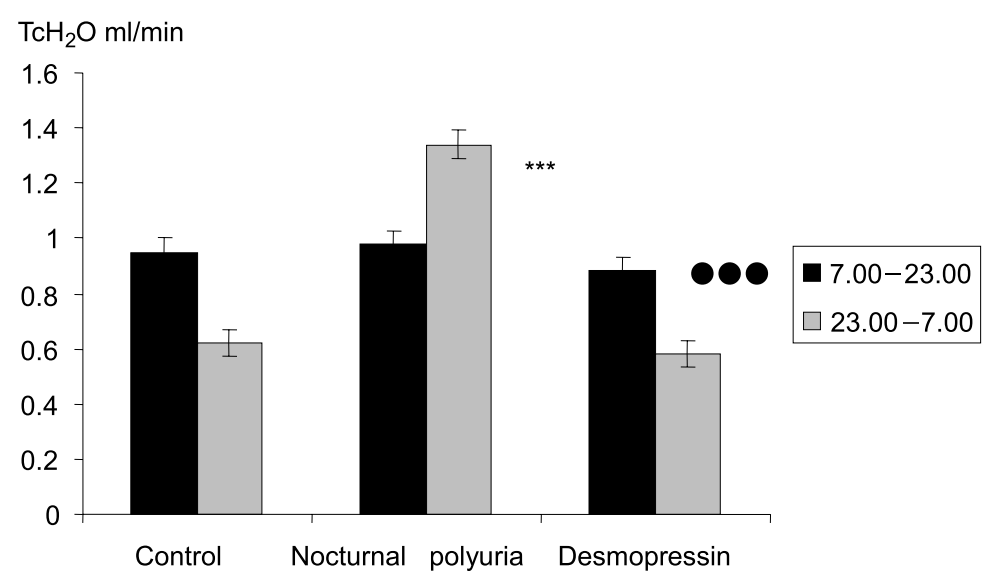

Picture 6. Effect of desmopressin on free water reabsorption in nocturnal polyuria

Picture 1-6: ${ }^{* *} \mathrm{p}<0.001-$ compared with the same parameter in control group; $\bullet \bullet \mathrm{p}<0.001-$ compared with the same parameter in nocturnal polyuria group. 


\section{Cosm $\mathrm{ml} / \mathrm{min}$}

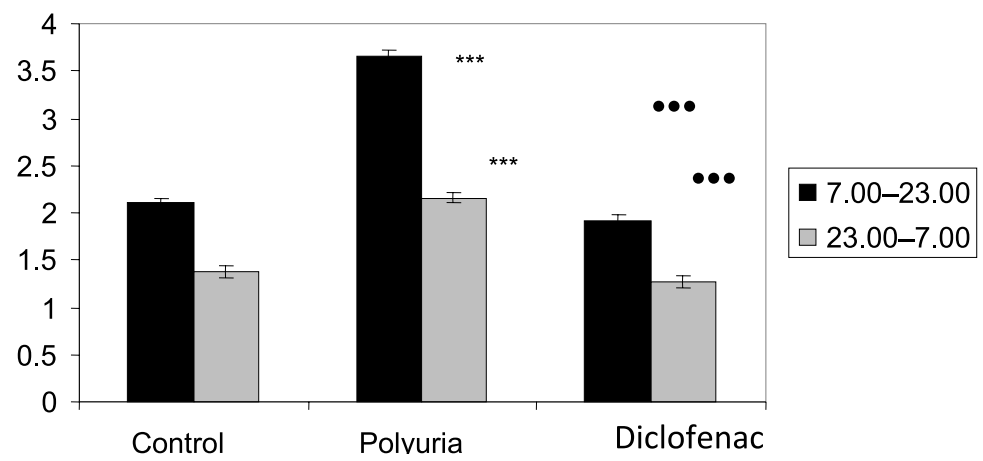

Picture 7. Effect of diclofenac on osmolal clearance in polyuria

$\mathrm{TcH}_{2} \mathrm{O} \mathrm{ml} / \mathrm{min}$

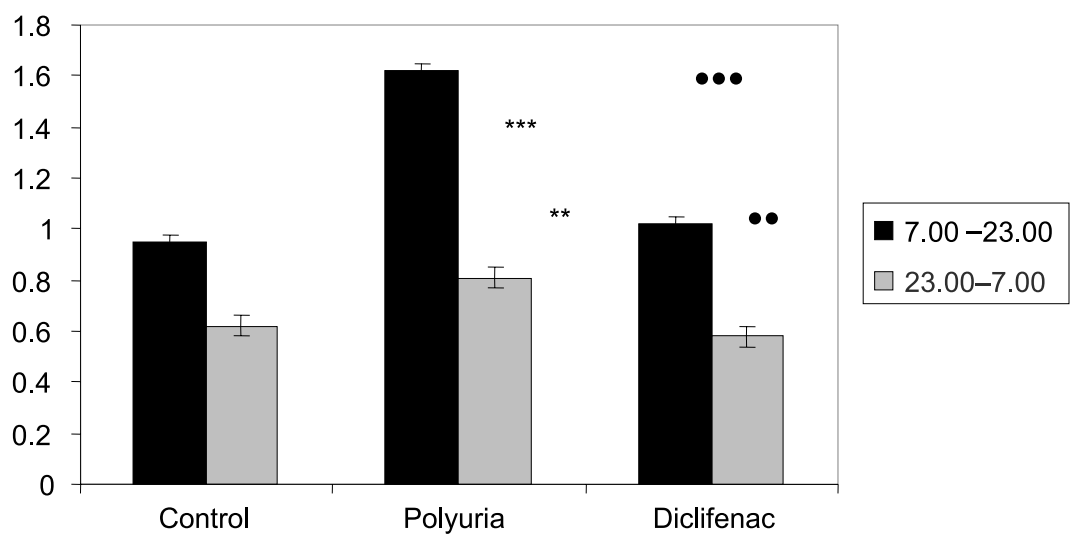

Picture 8. Effect of diclofenac on free water reabsorption in polyuria

$\mathrm{V} \mathrm{ml} / \mathrm{min}$

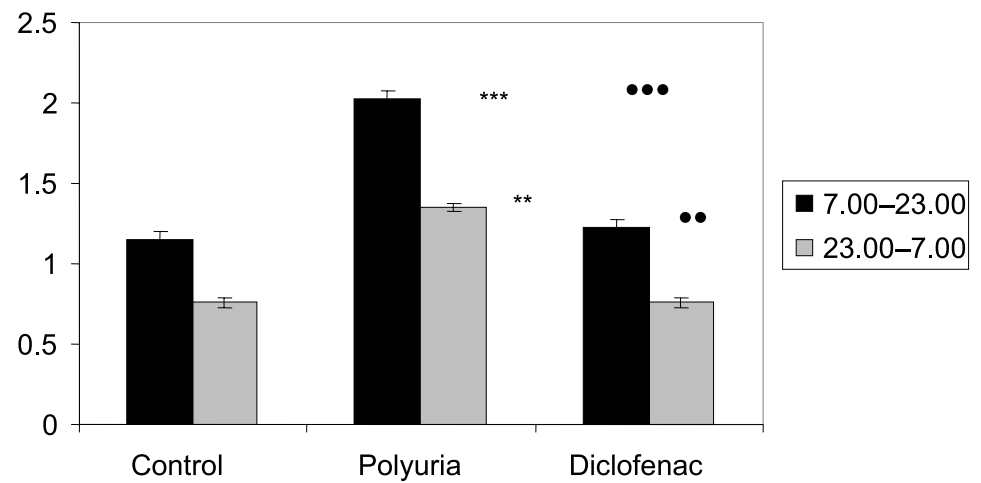

Picture 9. Effect of diclofenac on diuresis in polyuria

Picture 1-3: ${ }^{* *} \mathrm{p}<0.001,{ }^{* *} \mathrm{p}<0.01$ - compared with the same parameter in control group; $\bullet \bullet \bullet p<0.001, \bullet \bullet p<0.01$ - compared with the same parameter in polyuria group 


\section{$\mathrm{V} \mathrm{ml} / \mathrm{min}$}

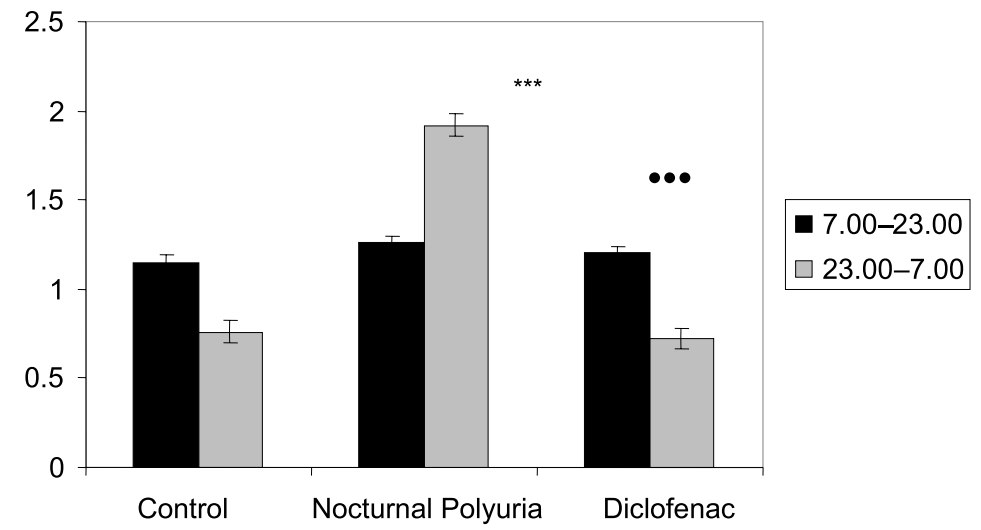

Picture 10. Effect of diclofenac on diuresis in nocturnal polyuria

\section{C osm $\mathrm{ml} / \mathrm{min}$}

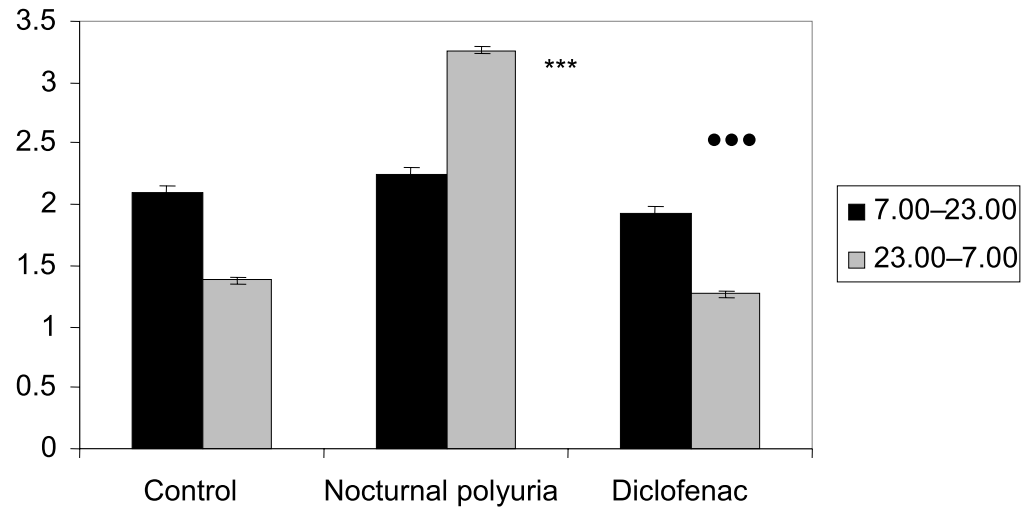

Picture 11. Effect of diclofenac on osmolal clearance in nocturnal polyuria

Picture 11-12: ${ }^{* * *} \mathrm{p}<0.001-$ compared with the same parameter in control group $\bullet \bullet p 0.001-$ compared with the same parameter in nocturnal polyuria group

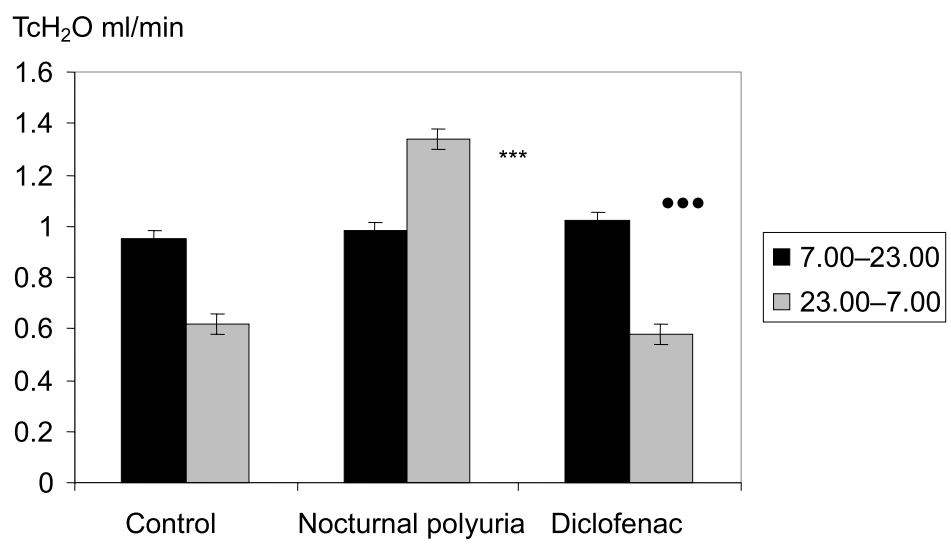

Picture 12. Effect of diclofenac on free water reabsorption in nocturnal polyuria 


\section{Discussion}

We have found that nocturia is a common symptom in incontinent women $(34.7 \pm 2.9 \%)$. Nocturia is more often in urge incontinence $(\mathrm{p}<0.01)$ and mixed incontinence $(\mathrm{p}<0.01)$ than in stress incontinence. The frequency of nocturnal polyuria and polyuria as nocturia factors is the same in stress, urge and mixed incontinence. We have found previously that in studied patients the cause of polyuria and nocturnal polyuria is a higher dieresis due to an elevated solute excretion (sodium, magnesium, potassium) [4]. In the current study we were interested in answering the following questions: in which part of nephron does the solute transport change with nocturnal polyuria and polyuria, which regulatory systems are responsible for the ion excretion, could these data be used for pathogenesis - based therapies?

Comparison of the rise in the sodium and magnesium ion excretion allows the localization of the disturbance of the renal function in the studied forms of nocturnal polyuria and polyuria. The thick ascending limb is known to reabsorb up to one-quarter the filtered sodium and about a half the filtered magnesium, while in subsequent parts of the distal tubule and in collecting ducts there is reabsorption of sodium ions but almost no magnesium ions are reabsorbed [5]. These results suggest there is a reduction of ion reabsorption in the thick ascending limb of the Henle loop in incontinent women with nocturnal polyuria and polyuria. Due to this defect, reabsorption of ions and water is decreased; as a result, lager volumes of fluid enter the collecting ducts.

As both desmopressin and prostaglandin E 2 affect the same cell of the thick ascending limb of Henle's loop, it is likely that nocturnal polyuria and polyuria result from a disturbed regulation of the function of these cells. Normalization can be achieved either by desmopressin administration to stimulate V 2 receptors, wich increase water permeability and water reabsorption in collecting ducts as well as ion reabsorption by cells of the thick ascending limb of Henle's loop, or by decrease in prostaglandin production via declofenac administration.

These results together with those of desmopressin and diclofenac efficiency in incontinent patients with nocturnal polyuria and polyuria suggest that the increase in diuresis and solute excretion might be due either to reduction of the effect of vasopressin on cells of the thick ascending limb of Henle's loop or to an increase in production of prostaglandins or both.

Diclofenac seems to be efficient in patients whose nocturnal polyuria or polyuria due to extra production of prostaglandinins which reduce the vasopressin effect. In a proportion of patients the defect is not associated with changed prostaglandin production, in these case only desmopressin is an effective treatment.

\section{References}

1. Sand P. K., Dmochowski R. R., Reddy J., Van der Meulen E. A. Efficacy and Safety of Low Dose Desmopressin Orally Disintegrating Tablet in Women with Nocturia: Results of a Multicenter, Randomized, Double-Blind, Placebo Controlled, Parallel Group Study. The Journal of urology, 2013, vol. 190 (3), pp. 958964.

2. Breyer M. D., Jacobson H. R., Hebert R. L. Cellular mechanisms of prostaglandin E2 and vasopressin interactions in the collecting duct. Kidney Int., 1990, vol. 38 (4), pp. 618-624.

3. Clinical guidelines for nocturia. Committee for Establishment of the Clinical Guidelines for Nocturia of the Neurogenic Bladder Society. Int. J. Urol., 2010, vol. 17 (5), pp. 397-409. 
4. Osipova N.A, Niauri D.A, Gzgzyan A.M. Ionoreguliruiushchaia funktsiia pochekpri razlichnykh tipakh nederzhaniia mochi u zhenshchin [Renal ionoregulation function in incontinent women]. Zhurnal akusherstva I zhenskikh boleznei [Journal of obstetrics and women's diseases], 2016, 65 (2), pp. 44-53. (In Russian)

5. Greger R. Renal handling of the individual solutes of glomerular filtrate. Comprehensive human physiology. Eds R. Greger, U. Windhorst. Berlin, Heidelberg, 1996, vol. 2, pp. 1517-1544.

For citation: Osipova N. A., Niauri D. A., Gzgzyan A. M., Dzhemlikhanova L. Kh. Correction of renal function by desmopressin and diclofenac in incontinent women with nocturia. Vestnik SPbSU. Medicine, 2017, vol. 12, issue 2, pp. 161-169. DOI: 10.21638/11701/spbu11.2017.205

Received: 21.11.2016

Accepted: 10.03.2017

Authors information:

Osipova Natalya A. — PhD, assistant; naosipova@mail.ru

Niauri Dariko A. — MD, Professor; d.niauri@mail.ru

Gzgzyan Alexandr M. - MD, Associate Professor; agzgzyan@mail.ru

Dzhemlikhanova Lyailya Kh. _ PhD, Associate Professor; dzhemlikhanova_l@mail.ru 